\title{
SEAWEED SPECIES COMPOSITION, ABUNDANCE AND DIVERSITY IN DRINI AND KONDANG MERAK BEACH, JAVA
}

\author{
Taufiq Ahmad Romdoni ${ }^{1}$, Ajeng Ristiani ${ }^{1}$, Maria Dyah Nur Meinita ${ }^{1 *}$, Bintang Marhaeni ${ }^{1}$, \\ Setijanto 1 \\ ${ }^{1}$ Faculty of Fisheries and Marine, Jenderal Soedirman University, Jalan dr. Soeparno GOR Soesilo \\ Soedarman Karangwangkal, Purwokerto
}

\begin{abstract}
The different characteristics of subtrate might give influence on species composition, abundance and diversity of seaweed. Kondang Merak and Drini Beach are two beaches in Java Island which have different subtrate characteristic. The aim of this study is to investigate seaweed composition, abundance and diversity in Drini Beach and Kondang Merak Beach. Survey method and quadrant transect sampling technique were applied in this study. The result showed that 13 species of seaweed were found at Drini Beach and 18 species of seaweed were found in Kondang Merak Beach. The composition of the seaweed at Drini Beach and Kondang Merak Beach were dominated by Rhodophyta (69\% and $56 \%)$. Enteromorpha flexuosa was the most abundant seaweed at Drini Beach, while at Kondang Merak Beach was dominated by Chaetomorpha crassa. The seaweed diversity index of Kondang Merak Beach $(2,08)$ was higher than Drini Beach $(1,27)$. Physical and chemical parameters were categorized as the optimal for the growth of the seaweed.
\end{abstract}

\section{Introduction}

Indonesia is an archipelago country located in tropical area with potential marine resources. Seaweed is the one of the coastal area's resources that has potential and can be explored. Seaweed is one of marine reources that widely spread habitat in Indonesia. Seaweed habitat distribution occur in intertidal area that has coral reef exposure. Among of the Indonesia's offshore, there are rocky Drini beach and Kondang Merak's beach are shores that has so many various species of seaweed.

Drini and Kondang Merak Beach are located in the southern of Java coastal area. Both of them are located in the different provinces, Drini is located in Special Region of Yogyakarta and Kondang Merak is located in Malang region, East Java Province. The difference of those two locations makes the enviromental characteritics becomes different. Besides the enviromental factor, human activity around those might affect the environmental characteristics. Drini beach is a tourism place that has so many visitors. Meanwhile, Kondang Merak beach has less human activity than Drini beach. It is caused by the location of Kondang Merak beach is a conservative area. Those two different

Corresponding author: ") maria.meinita@unsoed.ac.id 
characteristics might influence species composition, abundance and diversity of seaweed in both of locations.

Therefore, a study on species composition, abundance and diversity of seaweed in both of the beaches is needed. The aim of this study is to determine species composition, abundance and diversity of seaweed Kondang Merak Beach and Drini Beach.

\section{Materials and Methods}

Sampling were conducted in Drini Beach, Gunung Kidul, Special Region of Yogyakarta (S 8 $8^{\circ}$ '10.2" E 110 33'11.3”) and Kondang Merak Beach, Malang Regency, East Java (S

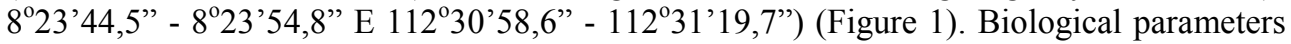
were measured consisted of seaweed composition, abundance and diversity index. Physical and chemical observed for supporting the biological data, consisted of $\mathrm{pH}$, salinity, temperature, light penetration, current velocity and type of substrate.
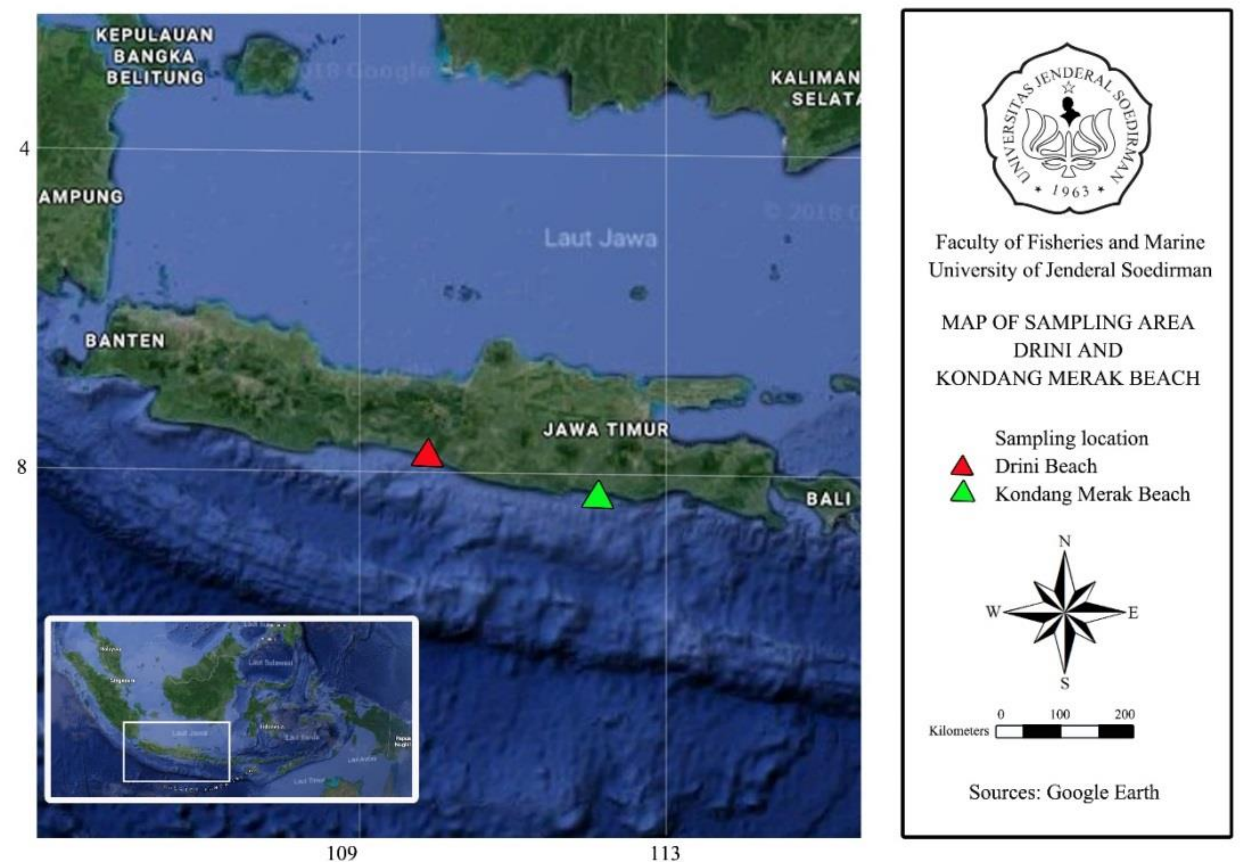

Fig 1. Map of Java Island and sampling area

Survey method with $1 \times 1$ square meter quadrant transects was applied in this study. Samples were collected during low tide period in both beaches. Each of the beach had three observation stations with triplicate. In each plot, physical, chemical and biological parameters were measured. Data were analysed using following formula $[1,2]$ :

Abundance

$$
D i=\frac{n_{i}}{A}
$$

$\mathrm{D}_{\mathrm{i}}=$ abundance species of $-\mathrm{i}\left(\mathrm{ind} / \mathrm{m}^{2}\right.$ )

$\mathrm{n}_{\mathrm{i}}=$ the total amount of species of $-\mathrm{i}$

$\mathrm{A}=$ total sampling area $\left(\mathrm{m}^{2}\right)$ 
Shanon Wiener diversity index:

$$
H^{\prime}=-\sum_{i=1}^{S} \frac{N i}{N} \log \frac{N i}{N}
$$

$$
\begin{array}{ll}
\mathrm{H}^{\prime} & =\text { Diveristy Index } \\
\mathrm{S} & =\text { amount of species } \\
\mathrm{Ni} & =\text { number of individual of species-i } \\
\mathrm{N} & =\text { total number of individuals }
\end{array}
$$

\section{Result and Discussion}

Thirteen species of seaweed was identified from study areas of Drini Beach. The seaweeds were divided into 3 Division, 6 Ordo, 8 Family, 11 Genus and 13 Species. The seaweed were obtained consisted of 3 species of Phaeophyta, 1 species of Phaeophyta and 9 species of Rhodophyta. While, in Kondang Merak Beach, 18 seaweed species were found, consisted of 6 species of Chlorophyta, 2 species of Phaeophyta and 10 species of Rhodophyta. Among the 3 division of seaweed, the highest division was Rhodophyta. The

\begin{tabular}{|c|c|c|c|c|c|}
\hline Class & Ordo & \multicolumn{2}{|l|}{ Family } & \multicolumn{2}{|r|}{ Species } \\
\hline Rhodophyceae & Gracilariales & \multicolumn{2}{|l|}{ Gracilariaceae } & \multicolumn{2}{|c|}{$\begin{array}{l}\text { Gracilaria edulis } \\
\text { Gracilaria salicornia }\end{array}$} \\
\hline & & \multicolumn{2}{|c|}{ Cystocloniaceae } & \multicolumn{2}{|c|}{ Hypnea charoides } \\
\hline & Gelidiales & \multicolumn{2}{|l|}{ Gelidiellaceae } & \multicolumn{2}{|c|}{$\begin{array}{l}\text { Gelidiella acerosa } \\
\text { Gelidium spinosum } \\
\text { Cryptonema }\end{array}$} \\
\hline & Ceramiales & \multicolumn{2}{|c|}{ Rhodomelaceae } & \multicolumn{2}{|c|}{$\begin{array}{l}\text { Laurencia papilosa } \\
\text { Acanthopora spicifera } \\
\text { Laurencia palisada }\end{array}$} \\
\hline \multirow[t]{2}{*}{ Chlorophyceae } & Cladophorales & \multicolumn{2}{|c|}{$\begin{array}{l}\text { Cladoporaceae } \\
\text { Siphonocladaceae }\end{array}$} & \multicolumn{2}{|c|}{$\begin{array}{l}\text { Chaetomorpha crassa } \\
\text { Boergesenia forbesii }\end{array}$} \\
\hline & Ulvales & \multicolumn{2}{|l|}{ Ulvaceae } & \multicolumn{2}{|c|}{ Entheromorpha flexuosa } \\
\hline Phaeophyceae & Dictyotales & \multicolumn{2}{|l|}{ Dictyotaceae } & \multicolumn{2}{|c|}{ Padina tenuis } \\
\hline \multicolumn{6}{|c|}{ B. Species of seaweed obtained from Kondang Merak Beach } \\
\hline Class & Ordo & Family & Ge1 & & Species \\
\hline \multirow[t]{3}{*}{ Chlorophyceae } & Ulvales & Ulvaceae & $\begin{array}{l}\text { Ulv } \\
\text { Ent }\end{array}$ & omorpha & $\begin{array}{l}\text { U. fasciata } \\
\text { E. compressa }\end{array}$ \\
\hline & Bryopsidales & $\begin{array}{l}\text { Caulerpaceae } \\
\text { Halimedaceae }\end{array}$ & $\begin{array}{l}\mathrm{Ca} \\
\mathrm{Hal}\end{array}$ & $\begin{array}{l}\text { rpa } \\
\text { leda }\end{array}$ & $\begin{array}{l}\text { C. serrulata } \\
\text { H. opuntia }\end{array}$ \\
\hline & Cladophorales & Cladophoraceae & Che & omorpha & $\begin{array}{l}\text { C. crassa } \\
\text { C. amteninna }\end{array}$ \\
\hline Phaeophyceae & Dictyotales & Dictyotaceae & $\mathrm{Pad}$ & & Padina minor \\
\hline
\end{tabular}
Rhodophyta in Kondang Merak Beach consisted of 10 species they were Gracilaria edulis, G. salicornia, Laurencia papilosa, Acanthophora spicifera, Acrocystis nana, Liagora sp, Galaxaura rugosa, Amphiroa fragilissima dan Gelideilla acerosa (Table 1).

Table 1. List of identified seaweed species in Drini and Kondang Merak Beach 


\begin{tabular}{|c|c|c|c|c|}
\hline \multirow[t]{9}{*}{ Rhodophyceae } & Gigartinales & Gracilariaceae & $\begin{array}{l}\text { Dictyota } \\
\text { Gracilaria }\end{array}$ & $\begin{array}{l}\text { D. dichotoma } \\
\text { G. salicornia } \\
\text { G. edulis }\end{array}$ \\
\hline & & Cystocloniaceae & Hypnea & Нурпеа sp. \\
\hline & Cerameales & Rhodomelaceae & Laurencia & L. papilosa \\
\hline & & & Acanthophora & A. spicifera \\
\hline & & & Acrocystis & A. nana \\
\hline & Nemaliales & Liagoraceae & Liagora & Liagora $\mathrm{sp}$ \\
\hline & & Galaxauraceae & Galaxaura & G. rugosa \\
\hline & Coralinales & Coralinaceae & Amphiroa & A. fragilissima \\
\hline & Gelidiales & Gelidiaceae & Gelidiella & G. acerosa \\
\hline
\end{tabular}

There are some differences of seaweed species which found in Drini and Kondang Merak Beach. Some species that occured in Drini were not found in Kondang Merak Beach. In the other way around, some seaweed species were found in Kondang Merak Beach but they were absent in Drini beach (Table 2).

Table 2. Comparison of seaweed recorded from Drini and Kondang Merak beach.

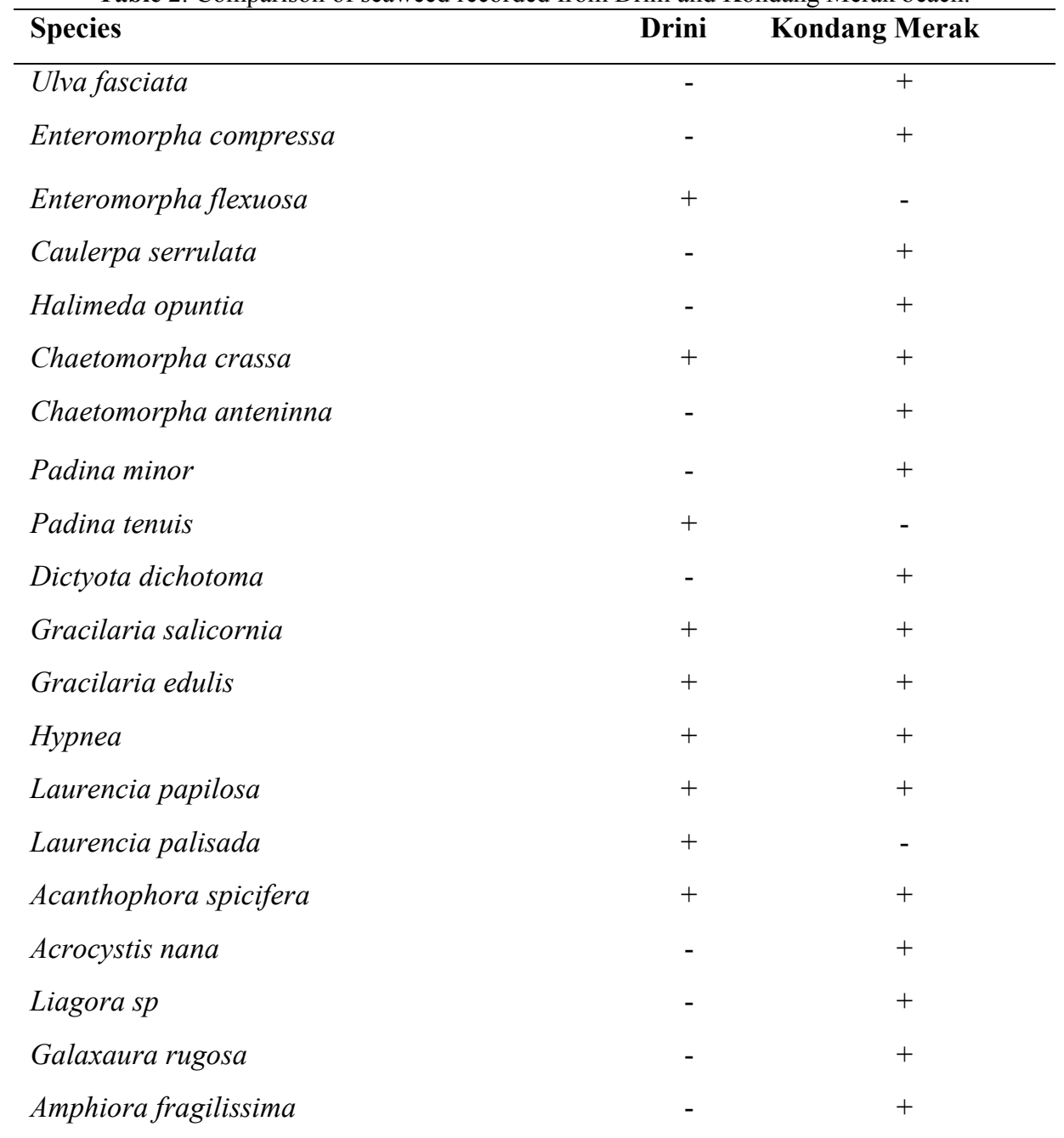


Gelidiella acerosa

Gelidium spinosum

Cryptonema

Boergesenia forbesii
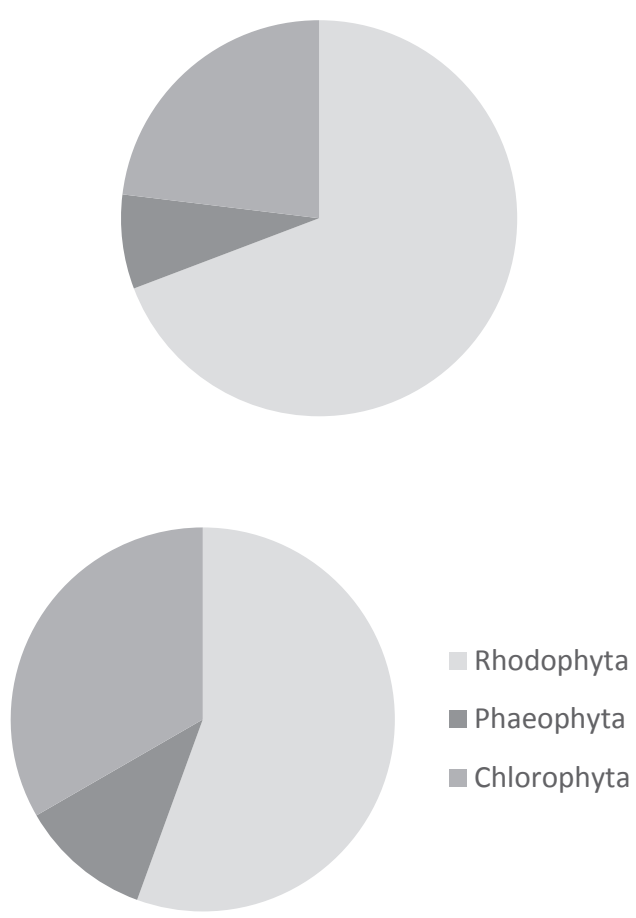

a.

b.

Fig 2. Composition of Seaweed species (a) Drini Beach and (b) Kondang Merak Beach

Division of Rhodophyta was the most abundant seaweed in the both of beaches (Figure $2)$. Rhodophyta have wider adaptability compared with chlorophyta and phaeophyta. Rhodophyta are found in large numbers in vertical zones between the sea level to the bottom of the sea that is less suited to the Phaeophyta and Chlorophyta. Dead coral substrate or dead coral fragments are the most suitable subtrate for genus Acanthophora, Codium, Gelidiella, Galaxaura, Jania, Amphiroa and Gracilaria [3]. Present study showed that the abundance of Rhodhophyta on Drini and Kondang Merak Beach, might have relate with types of the substrate which is dominanted by rocky substrate. 


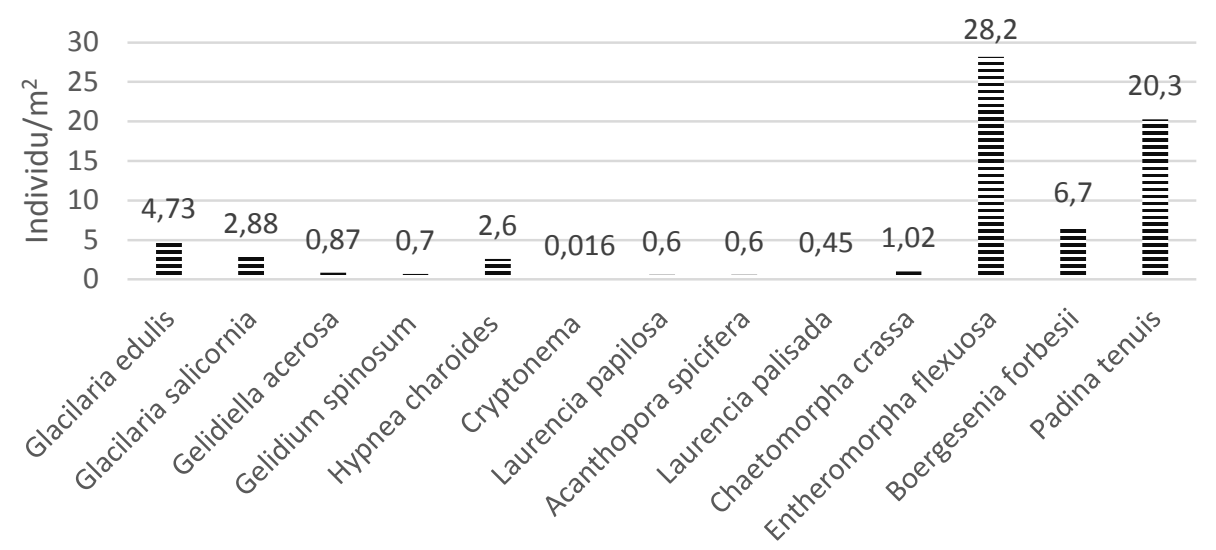

Species

(a)

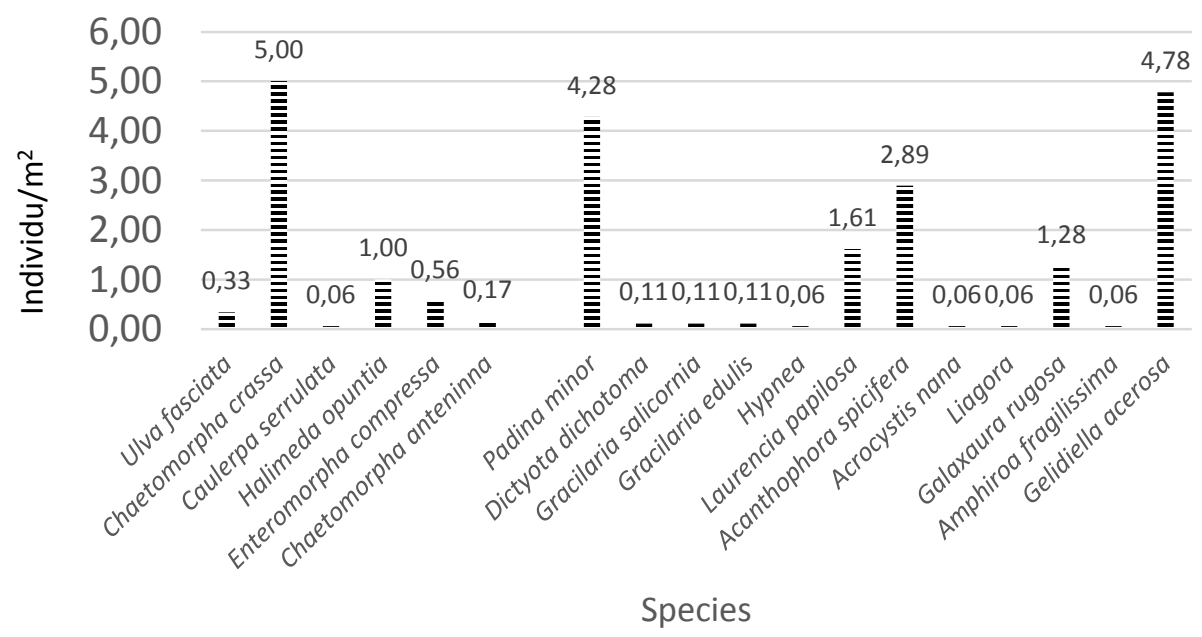

(b)

Fig 3. Abundance of seaweed (a) Drini Beach, (b) Kondang Merak Beach

Enteromorpha flexuosa was seaweed species with the highest abundance in Drini Beach. The abundance of this species might be caused by the influence of physical and chemical factors in the environment as well as the influence of the morphology of the species of seaweed. Physical and chemical environmental factors in this zone is supportive to the growth of the zone where it is passed by the huge waves. While the highest abundance of seaweed on the Kondang Merak Beach was Chaetomorpha crassa. This species grows on rocky substrates in the intertidal up to subtidal zone or areas that are always exposed to the air during low tide [4]. 


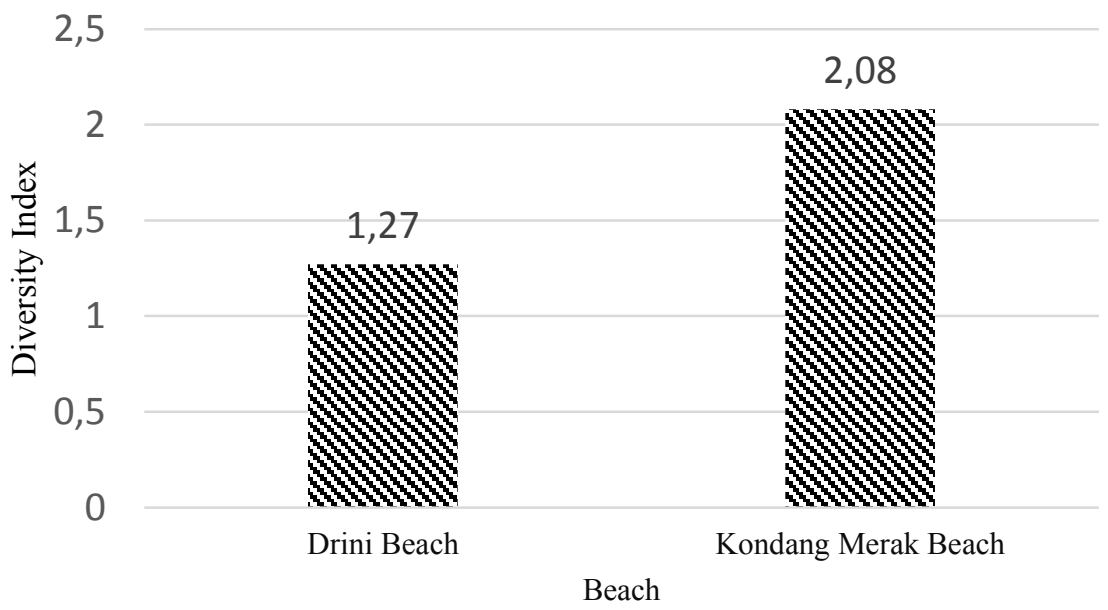

Fig 4. The diversity index were measured at Drini Beach and Kondang Merak Beach.

Diversity index of the Kondang Merak Beach is higher than Drini Beach. High and low values of the diversity index can be influenced by a number of species, the quantity of seaweed, and the balance of species distribution [5]. The level of diversity of seaweed on Drini and Kondang Merak Beach can also be caused by human activity. Drini beach as a tourism place, can have an impact on the community structure of seaweed due to human activities. Diversity of species tends to be low because of the disruption of an ecosystem [6]. Increased rates of tourists is one of the causes of the disruption of biological diversity [7].

Table 4. Comparison of physical and chemistry were measured in Drini and Kondang Merak Beach

\begin{tabular}{lll}
\hline Parameters & Drini & Kondang Merak \\
\hline $\mathrm{pH}$ & $8,0 \pm 0,0$ & $8,0 \pm 0,0$ \\
Salinity $(\mathrm{ppt})$ & $30,0 \pm 0,0$ & $31,9 \pm 0,3$ \\
Temperature $\left({ }^{\circ} \mathrm{C}\right)$ & $30,0 \pm 0,07$ & $28,7 \pm 0,9$ \\
Light Penetration $(\mathrm{cm})$ & $25,0 \pm 0,0$ & $14,11 \pm 4,26$ \\
Current $(\mathrm{m} / \mathrm{s})$ & $0,33 \pm 0,0$ & $1,03 \pm 0,11$ \\
Substrate & Rocky substrate & Rocky Substrate \\
\hline
\end{tabular}

The type of substrate in both Drini and Kondang Merak beach were rocky substrate. The type of substrate is an important factor that affects the existence of seaweed, this is because the substrate becomes a place for seaweed to attach themselves. The rocky substrate is stable, hence the seaweed can be strongly attached to the substrate so it is not easy to crash when high wave attack. The results showed that $\mathrm{pH}$ at Drini Beach and Kondang Merak still belong to a good range for seaweed growth. Seaweed can grow optimally in the $\mathrm{pH}$ range of 6.8 to 9.6 [7].

Kondang Merak Beach had a higher salinity than Drini Beach. Based on the salinity at Drini Beach and Kondang Merak, generally the condition of coastal waters is still good enough to support the growth of seaweed. The optimum salinity range for sea weed growth is 30-35 ppt [7, 8, 9]. Drini Beach had higher temperature than Kondang Merak Beach. 
However the temperature is still within in the optimum range for seaweed grow. The high temperature might effect seaweed survival [10]. The current in Kondang Merak Beach was stronger than than Drini Beach. The movement of currents in the waters of Kondang Merak Beach might be influenced by the current pattern that occurs from the wave fragments due to the occurence of small islands in the southern part of the beach. Water movement serves to supply nutrients also help seaweed absorb nutrients, and carry out the exchange of oxygen. The result of light penetration measurement on both beaches is the result of $100 \%$ brightness measurement. Penetration of light can still penetrate to the bottom of the water. Light penetration is strongly influenced by weather conditions, measurement time, turbidity, suspended solids, and the level of vision of the researcher [11].

\section{Conclusion}

The different environmentalcharacteristic of beach and human activity might affect seaweed abundance, composition and diversity in Drini and Kondang Merak Beach. Enteromorpha flexuosa was the most abundant species in Drini Beach, while the highest abundance species in Kondang Merak Beach was Chaetomorpha crassa. Rhodophyceae was the highest class in Drini Beach and Kondang Merak Beach. Kondang Merak Beach has a seaweed diversity higher than Drini Beach.

We thank Jenderal Soedirman University for providing financial support through Riset Unggulan Terapan 2018 Research Grant.

\section{References}

1. C.J Dawes. Marine Botany. John Wiley and Sons, Inc., Canada, 628pp (1981)

2. V.K Dhargalkar, D. Kavlekar, Seaweeds: A field manual. National Institute of Oceanography, New Delhi, 36pp. (2004)

3. H. Arfah, S. Papalia, Kepadatan dan Keragaman Jenis Rumput Laut di Perairan Pesisir Teluk Weda, Propinsi Maluku Utara. Jurnal Ilmu dan Kelautan Tropis. 7 (2): 745 755. (2015)

4. Jr. G. C. Trono,. Field Guide and Atlas of the Seaweed Resources of the Philippines. Bookmark. Makati (1997)

5. F. Hadi, I. J. Zakaria, Z. Syam, Diversity of Macroalgae in Kasiak Gadang Island Nirwana Beach, Padang-West Sumatra, Indonesia. The Journal of Tropical Life Science. 6 (2): 97-100 (2016)

6. H. Sormin, G. S. Gerung, U.N.W.J. Rembet, Struktur Komunitas Rumput Laut di Pulau Mantehage, Provinsi Sulawesi Utara. Aquatic Science \& Management. 3 (2): 32-37 (2015)

7. V.S.K. Chennubhotla, K.S. Rao, N. Kaliaperumal, Effect of Some Adverse Factors on the Diversity and Distribution of Marine Macro Algae Along the Indian Coasts. Seaweed Research and Utilization Association. 36 (1): 5-11. (2015)

8. K. Lüning, Seaweeds: Their Environment, Biogeography and Ecohysiology. John Willey \& Sons, Inc. New York. 230 p. (1990).

9. J.W Nybakken,. Biologi Laut Pendekatan Ekologis. PT Gramedia Pusaka. Jakarta (1992)

10. L Sumich, An Introduction to The Biology of Marine Life. Wmc Brown. Dubuque. Lowa (1992)

11. H. Effendi, Telaah Kualitas Air. PT Kanisius. Yogyakarta. (2003) 